\title{
USE OF WATER-SOLUBLE PRECURSORS IN THE PRODUCTION OF CAST METAL FOAMS
}

\author{
UPORABA VODOTOPNIH DODATKOV V PROIZVODNJI LITIH \\ KOVINSKIH PEN
}

\author{
Ivana Kroupová ${ }^{1 *}$, Petr Lichý1, Ivo Lána ${ }^{2}$ \\ ${ }^{1}$ VSB - Technical University of Ostrava, Faculty of Materials Science and Technology, Department of Metallurgy and Foundry, 17. listopadu \\ 2172/15, 70800 Ostrava - Poruba, Czech Republic \\ ${ }^{2}$ SaM Nové Ransko, s.r.o., Nové Ransko 234, 58263 dírec nad Doubravou, Czech Republic \\ Prejem rokopisa - received: 2019-08-01; sprejem za objavo - accepted for publication: 2019-08-18
}

doi:10.17222/mit.2019.144

\begin{abstract}
The paper is devoted to the field of manufacturing cast metallic foams - porous metal materials - with a stochastic arrangement of the inner cavities. The mastering of inexpensive ways of manufacturing metallic foams is a prerequisite for a full utilization of such a material. That is why the experimental part was devoted to the casting technologies for the production of metal foams based on conventional foundry processes. In the experiment, the infiltration of molten metal into mould cavities filled with precursors was tested. Particular attention was paid to the use of water-soluble precursor materials. It is assumed that a thorough knowledge of the production parameters and conditions will contribute to the expansion of the foundry range, which can also increase the competitiveness of this industry on a global scale.

Keywords: metallic foams, salt, water-soluble, casting
\end{abstract}

Pričujoči članek opisuje izdelavo litih kovinskih pen, to je poroznih kovinskih materialov s stohastično (naključno) porazdelitvijo notranjih praznin oz. por. Umetnost obvladovanja cenenih poti proizvodnje kovinskih pen je temelj za izkoriščanje uporabnosti tega materiala. Avtorji članka so se v eksperimentalnem delu tako posvetili tehnologijam litja v proizvodnji kovinskih pen, ki temeljijo na konvencionalnih livarskih postopkih. S praktičnim preizkusom so testirali potek infiltracije raztaljene kovine $\mathrm{v}$ votlino modela, polnjeno s prekurzorji - izhodnimi dodatki. Posebno pozornost so posvetili vodotopnim prekurzorjem. Zaključujejo z ugotovitvijo, da poznavanje parametrov proizvodnje in pogojev te vrste proizvodnje, prispeva $\mathrm{k}$ razširitvi livarskega programa, kar lahko tudi poveča njihovo konkurenčnost na globalnem trgu.

Ključne besede: kovinske pene, sol, vodotopnost, livarstvo

\section{INTRODUCTION}

A metal foam is a material, which has attracted a great deal of attention in many areas of human activities in recent years. This porous metal material has unique features that can be combined with each other. They are characterized by, e. g., low density, high specific surface area, acoustic or thermal insulation properties, etc. ${ }^{1}$ Thanks to these properties, metal foams can be used in a wide range of sectors of human activity from vehicle construction, thermal engineering to medicine. However, the application potential of these materials is limited by the economic requirements of their production technologies. In most cases, these are costly methods based on complicated procedures and the use of non-standard and expensive input materials. ${ }^{2-4}$

At the Faculty of Materials Science and Technology, VSB-TUO, Department of Metallurgy and Foundry, the possibilities of producing metal foams from the liquid phase, namely using the foundry method, are studied. One of the studied technologies is the infiltration of liquid metal into a mould cavity filled with precursors.

*Corresponding author's e-mail:

ivana.kroupova@vsb.cz (Ivana Kroupová)
The use of standard casting processes and standard materials makes it possible to identify affordable materials, thereby making a full use of their application potentials. The casting technology also offers the possibility of producing very complex parts, both with a solid surface layer and without it.

\section{EXPERIMENTAL PART}

Since the discovery of porous metallic materials, numerous methods of production have been developed. According to the state, in which a metal is processed, the manufacturing processes can be divided into four groups - metal foams can be made from a liquid metal, powdered metal, metal vapours or metal ions. ${ }^{1}$

In this research, we are interested in manufacturing metal foams from a liquid metal, especially by way of the foundry methods. There are several foundry methods for the production of porous metals, such as the investment-casting technology (using an evaporative pattern), which is considerably expensive. ${ }^{5}$ Thanks to the foundry technology we are able to control the porosity (\%), pore size and their distribution (regular/irregular). In our case, the production of metal foams with an irregular structure is carried out by pouring filling materials (precursors) 
into a mould cavity. These precursors are metal encapsulated and removed from the casting volume after the solidification of the metal. The condition for their complete removal is a mutual contact of all the precursors.

In all the experiments, the castings were made of an Al-Si-type alloy (AlSi10MgMn) and the moulds were made from a commonly used moulding mixture (green sand).

\subsection{Principle of the technology}

The irregular distribution of pores that we deal with can be achieved with the use of various types of precursors, filling in a mould cavity (Figure 1). A precursor must be made of a material that preserves its shape at the impact of molten metal (having sufficient strength, low abrasion, refractoriness) and it must also allow a good disintegration after the casting. ${ }^{6}$

The key step in this technology is a perfect removal of all the precursors from the casting volume, which is problematic due to the complex cavity of a casting. This is why our experiment focused on water-soluble materials for the precursors.

\subsection{Salt precursors}

The tested filler materials were precursors with a salt-based core composition. These materials were included in the experiment because of the ease of their removal from the casting volume after the casting. The composition of the moulding mixture for the precursors included crystalline sodium chloride $\mathrm{NaCl}$ (foundry sand) and water glass, $M=2.38$ (the binder). The hardening was done in a microwave oven $(3 \times 2 \mathrm{~min})$ at $1000 \mathrm{~W}$.

From the prepared moulding mixture, beams were made, which were cured and subsequently cut into cubes. These semi-finished products were placed on a rotating screen where they were tumbled. The proposed technology ensures the production of the precursors of
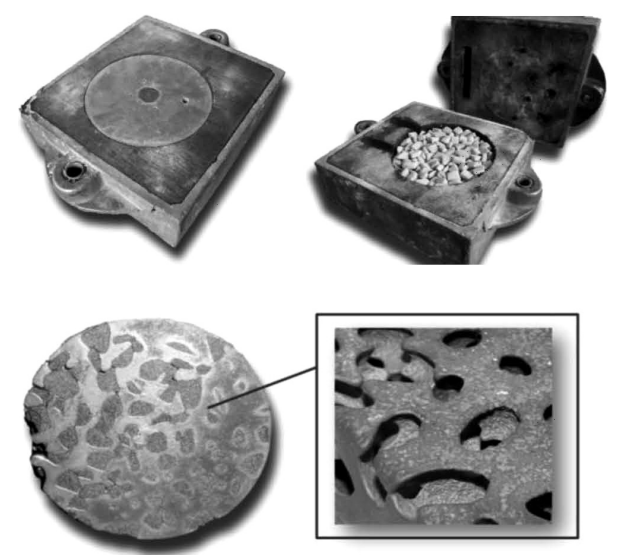

Figure 1: Principle of the liquid-metal infiltration into a mould cavity filled with precursors; from the left: the mould, the mould cavity filled with precursors, a metal-foam casting and its detail after the removal of the precursors

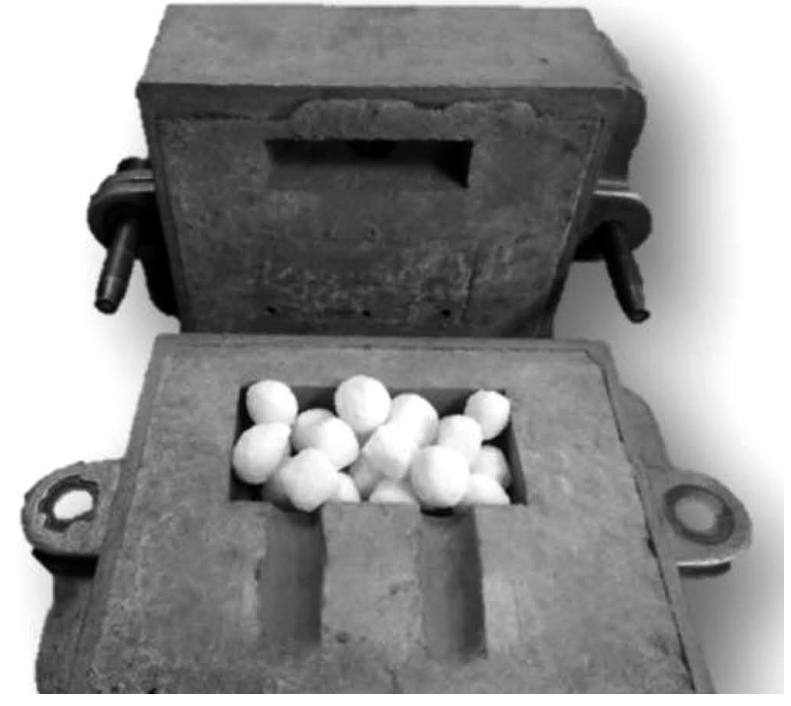

Figure 2: Mould cavity filled with salt precursors

the same size, shape and properties. The mould cavity with dimensions of $30 \times 60 \times 120 \mathrm{~mm}$ was filled with precursors (Figure 2) and after the mould was manufactured, the melt - the AlSi10MgMn aluminum alloy with a casting temperature of $730{ }^{\circ} \mathrm{C}$ - was infiltrated. Four minutes after the casting process, the casting was immersed into water to flush the precursors out. An example of the resulting casting is shown in Figure 3.

\section{RESULTS}

Special materials and technologies for manufacturing precursors were tested. The porosity of the produced castings amounted to $60 \%$. The use of salt precursors seems to be very suitable in view of their removal from the casting volume. After casting, these can be removed immediately after the solidification of the cast by flushing them out of all internal cavities (assuming the precursors touch each other to form interconnected cavities). Thus, the complicated process of mechanical removal of the filler material, which used to be a common disadvantage of all the processes using precursors made of standard moulding mixtures, is now eliminated. ${ }^{7}$ This way, the manufacturing of precursors allows the formation of the same size, shape and the resulting characteristics of precursors.

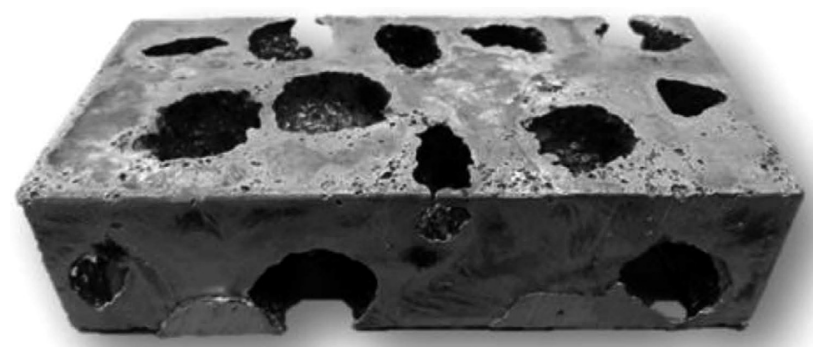

Figure 3: Casting after the salt precursors have been removed by flushing 


\section{DISCUSSION}

During the experiment, the use of special water-soluble moulding mixtures for the manufacture of precursors was confirmed. In view of the possibility of removing the precursors from the complex structure of a casting, it is particularly advantageous to use salt precursors. This process of manufacturing metallic foams fully complies with the original requirements - it is a low-cost technology based on the commonly used foundry operations.

\section{CONCLUSIONS}

With the method of infiltrating molten metal into a mould cavity filled with precursors, foams with irregular internal structures can be prepared from the materials that are normally processed in the foundry operations. It is necessary to know the technological and metallurgical parameters of the production for a successful casting. It is assumed that a thorough knowledge of the production parameters and conditions will contribute to the expansion of the foundry range, which can also increase the competitiveness on a global scale.

\section{Acknowledgment}

This contribution was carried out with the support of the Technology Agency of the Czech Republic TH02020668 and TA02011333, and the support of the projects within "the Student Grant Competition", with numbers SP2020/39 and SP2020/64.

\section{REFERENCES}

${ }^{1}$ J. Banhart, Manufacture, characterisation and application of cellular metals and metal foams, Progress in Materials Science, 46 (2001) 6, 559-632, doi:10.1016/S0079-6425(00)00002-5

${ }^{2}$ F. García-Moreno, Commercial Applications of Metal Foams: Their Properties and Production, Materials, 85 (2016) 9, doi:10.3390/ ma9020085

${ }^{3}$ L. Drenchev, J. Sobczak, S. Malinov, W. Sha, Gasars: A class of metallic materials with ordered porosity, Materials Science and Technology, 22 (2006) 10, 1135-1147, doi:10.1179/174328406X118302

${ }^{4}$ L. J. Gibson, Biomechanics of cellular solids, Journal of Biomechanics, 38 (2005), 377-399, doi:10.1016/j.jbiomech.2004.09.027

${ }^{5}$ I. Kroupová, P. Lichý, F. Radkovský, J. Beňo, V. Bednářová, I. Lána, Optimization of the annealing of plaster moulds for the manufacture of metallic foams with an irregular cell structure, Mater. Tehnol., 49 (2015) 4, 527-530, doi:10.17222/mit.2014.132

${ }^{6}$ I. Kroupová, F. Radkovský, P. Lichý, V. Bednářová, Manufacturing of cast metal foams with irregular cell structure, Archives of Foundry Engineering, 15 (2015) 2, 55-58, doi:10.1515/afe-2015-0038

${ }^{7}$ I. Kroupová, P. Lichý, V. Merta, I. Lána, Use of Precursors for the Production of Cast Metallic Foams, Mater. Tehnol., 53 (2019) 2, 189-191, ISSN 1580-2949, doi: 10.17222/mit.2018.141 